\title{
Runoff and sediment yield modeling in a medium-size mediterranean watershed
}

\author{
Ossama. M.M. Abdelwahab, Tiziana Bisantino, Fabio Milillo, Francesco Gentile \\ Department of Agro - Environmental and Territorial Science (DISAAT), University of Bari, Italy
}

\begin{abstract}
The AnnAGNPS model was used to estimate runoff, peak discharge and sediment yield at the event scale in the Carapelle watershed, a Mediterranean medium-size watershed $\left(506 \mathrm{~km}^{2}\right)$ located in Apulia, Southern Italy. The model was calibrated and validated using five years of runoff and sediment yield data measured at a monitoring station located at Ordona - Ponte dei Sauri Bridge. A total of 36 events was used to estimate the output of the model during the period 2007-2011, in comparison to the corresponding observations at the watershed outlet. The model performed well in predicting runoff, as was testified by the high values of the coefficients of efficiency and determination during the validation process. The peak flows predictions were satisfactory especially for the high flow events; the prediction capability of sediment yield was good, even if a slight over-estimation was observed. Finally, the model was used to evaluate the effectiveness of different Management practices (MPs) on the watershed (converting wheat to forest, using vegetated streams, crop rotation corn/soybean, no tillage). While the maximum reduction in sediment yield was achieved converting wheat to forest, the best compromises between soil conservation and agriculture resulted to be crop rotations.
\end{abstract}

Correspondence: Ossama. M.M. Abdelwahab,

Department of Agro - Environmental and Territorial Science (DISAAT),

University of Bari, via Amendola 165/A 70126 Bari (Italy).

Tel. +39.080 .5442211 - Fax: +39.80 .5443061 .

E-mail: el.khwaga_eng@yahoo.com

Key words: watershed modeling, AnnAGNPS, suspended sediment transport, Best Management practices, crop rotation.

Acknowledgements: the present work was financially supported by the Italian Ministry of Education, Universities and Research (MIUR), Project "National network for monitoring, modelling and sustainable management of erosion processes in agricultural land and hilly-mountainous area", in the framework of the PRIN 2010-2011.

(C) Copyright O.M.M. Abdelwahab et al., 2013

Licensee PAGEPress, Italy

Journal of Agricultural Engineering 2013; XLIV(s2):e7

doi:10.4081/jae.2013.s2.e7

This article is distributed under the terms of the Creative Commons Attribution Noncommercial License (by-nc 3.0) which permits any noncommercial use, distribution, and reproduction in any medium, provided the original author(s) and source are credited.

\section{Introduction}

Soil erosion can lead to reduction of soil fertility, loss of nutrients, and declines of crop yields in farmlands. In a review of mechanized agricultural systems in which wheat, corn, soybean and barley were planted, Bakker et al. $(2004,2005)$ found that on average, soil erosion reduced crop productivity by about $4 \%$ for each $10 \mathrm{~cm}$ of soil lost. In recent years, it is widely recognized that more site-specific approaches are needed to assess variations in erosion susceptibility in order to select the most suitable land management method (Pandey et al., 2008). Structural and non structural measures to control negative impacts of runoff and erosion processes can be properly addressed through reliable prediction models. Although there has been considerable effort, additional work is needed to assess and improve the reliability of available prediction models in different environmental contexts. Reliable prediction models can help to select the most practical and effective tools in reducing erosion problems and developing appropriate land use planning (Licciardello et al., 2007).

Continuous distributed simulation models (as AnnAGNPS, WEPP, SWAT) provide great advantages as they allow watersheds response to be studied over a longer time period and can help to select the most practical and effective tools in reducing erosion problems (Zema et al., 2010).

AnnAGNPS has been implemented to assess runoff and water quality as well as sediment yield in small to large watersheds under different environmental conditions. Assessments of model performance, frequently coupled with calibration/validation trials in monitored watersheds ranging from 32 ha to $2500 \mathrm{~km}^{2}$, have recently been published (Licciardello et al., 2007; Yuan et al., 2008; Parajuli et al., 2009; Zema et al., 2010)

Few studies have been conducted using AnnAGNPS at the watershed scale in semi-arid environments. Here the quantification of sediment transport is quite difficult due to the high variability of rainfalls and water flows. The semi-arid areas receive low annual rainfall, have nutrient-poor soils, short-grass or shrublands vegetation and the actual evapotranspiration is recognised as the main hydrologic loss (50-60 $\%$ of the mean annual rainfall). In particular, after long-lasting periods with no rains and high temperatures, the soil can be very dry at the time of the storm. On the contrary in humid and hyper-humid climates, because of the high number of rainy days, the rainfall responsible for the flood peak is likely to occur when the infiltration rate into the soil is close to the gravitational capacity (Fiorentino and Iacobellis, 2001).

With particular reference to the Mediterranean environment, tests of the single-event model AGNPS were carried out in Italy, where hydrological effects of different land uses in an alpine environment (Cazorzi and Dalla Fontana, 1996; Cazorzi, 1996; Lenzi and Di Luzio, 1997) as well as soil erosion in southern small watersheds characterized by ephemeral streams (Morgagni et al., 1993; Licciardello and Zimbone, 2002) were successfully predicted.

In order to estimate erosion and sediment transport processes in semi-arid environments the AnnAGNPS - Annualized Agricultural Non- 
point Source model was selected and applied in the Carapelle watershed (Southern Italy). The model structure is suitable as it contains both empirical and quasi-physically based algorithms, it is fully distributed with land surface runoff and sediment processes modelled for the individual grid cell, and the output is routed to the catchment outlet. The data requirements and computational complexity of the AnnAGNPS allow the model to be used as a tool for watershed management planning. (Bisantino et al, 2013).

The AnnAGNPS model was developed to analyze and provide estimates of runoff with primary emphasis upon sediment and nutrients transport from agricultural watersheds, and to compare the effects of various conservation alternatives. Simulations under various combinations of different scenarios of land and water management can provide comparative analysis of different options and prove to be very useful as a guide to what Best Management Practices (BMPs) can be adopted to minimize pollution from point and nonpoint sources (Shrestha et al., 2006).Best Management Practices (BMPs) are structural and nonstructural approaches used to reduce pollutant loads in watersheds draining both urban and rural areas. The Soil and Water Conservation Society (SWCS) defines a BMP as "a practice or combination of practices that are determined by a state or designated area-wide planning agency to be the most effective and practicable (including technological, economic, and institutional considerations) means of controlling point and nonpoint source pollutants at levels compatible with environmental quality goals" (Barry et al., 2001).

Vegetation plays a critical role in flow resistance, particularly in relation to relaxation times and thresholds for flood erosion effects. Because of the resistance of vegetation-mantled banks and flood plains, there may be progressive, long-term encroachment of vegetation into the channel, especially on small streams. This vegetation increases roughness so reduces flow conveyance (Wolman and Gerson, 1978). The vegetation could retain from 30 to 70 percent of the deposited sediments. The ability of vegetation to entrap and retain sediment is related to the length and cross-sectional area of the vegetation (Thornton et al., 1997). Early research on the hydrologic impacts of vegetation management practices began in the 1910 s, was expanded into the 1930s and 1940s, and continuing in the 1980s to further evaluate the effects of vegetation manipulations on the basin's water resources and other multiple uses (Zou et al., 2010). The impact of vegetation on the system is overwhelming. Vegetation produces an erosion-resistant peat layer, stabilizes channel banks and slows down the water flow. Vegetation also stimulates aggradation of bed load material on the channel bottom, and contributes to avulsion by blocking the channels. The channel network owes its origin to repeated though infrequent avulsion (Gradzinski et al., 2003).

Another important management practice is the no-till farming. Notill farming, due to an associated increase in surface residue and reduction in surface runoff, has been recommended as a best management practice to reduce soil erosion. Surface residues affect erosion by decreasing the soil surface area susceptible to raindrop impact, reducing the velocity of runoff and hence its transport capacity, and by creating mini-ponds that result in deposition behind clumps of residue (Fu et al., 2006).

Another conservation practice is the crop rotation (often called conservation crop rotation), that is defined as the use of different crops in a specified sequence on the same farm field. There are several reasons for using crop rotations; although the primary one is to reduce soil erosion, thereby reducing the quantities of sediment and sediment-bound pollutants such as nitrogen, phosphorus and pesticides. (Barry et al., 2001).

The objective of this paper is to evaluate the AnnAGNPS model prediction capability for runoff and sediment yield using a five years data base in a middle sized Mediterranean watershed located in Southern
Italy. A continuous simulation process of runoff and sediment yield has been carried out comparing the simulation outputs to the corresponding observed data measured during the period 2007-2011. A calibration process for the model parameters that have a large impact on the prediction capacity of the model has been performed at the event scale utilizing the events recorded in the period $2007-2008$, then a validation process to evaluate the model performance using the events recorded in the period 2009-2011. Finally, after validation, the model has been used to evaluate the effectiveness of alternative MPs on sediment yield at the watershed scale.

\section{Materials and methods}

\section{AnnAGNPS Model Description}

The Annualized Agricultural Nonpoint Source Pollution model (Theurer and Cronshey, 1998; Bingner and Theurer, 2005; USDA-ARS, 2006) was developed by the USDA Agricultural Research Service (ARS) and Natural Resources Conservation Service (NRCS) to predict sediment and chemical delivery from un-gauged agricultural watersheds up to 300,000 ha (Bosch et al., 2001). AnnAGNPS is a continuous simulation, grid-based, batch-process computer program where runoff, sediment, nutrients and pesticides are routed from their origins in upland grid cells through a channel network to the outlet of the watershed (Binger and Theurer, 2005). The climatic data requirements for simulations include daily maximum and minimum temperature, precipitation, average daily dew point temperature and wind speed, and sky cover (Bingner and Theurer, 2005). The ArcView interface for AnnAGNPS incorporates the Generation of weather Elements for Multiple applications (GEM) climate generation model (USDA-ARS, 2005) which generates daily precipitation, maximum and minimum temperature, and solar radiation. AnnAGNPS users also have the option to input measured climate data by uploading the data into the input editor.

AnnAGNPS hydrology is based on a simple bookkeeping of inputs and outputs of water during the daily time steps (Bingner and Theurer, 2005). The hydrologic processes simulated in the model include interception, evaporation, surface runoff, and evapotranspiration, subsurface lateral flow and subsurface drainage (Yuan et al., 2006). In AnnAGNPS, runoff is predicted using the SCS curve number technique (USDA-SCS, 1986), and sheet and rill erosion are predicted with the Revised Universal Soil Loss Equation (RUSLE, Renard et al., 1997). Soil moisture balance is calculated on a sub-daily time step using a simple constant-time step procedure for both the tillage and below tillage composite soil layers (Bingner and Theurer, 2005). Sediment transport in channels is computed using a modified Einstein equation, and the Bagnold (1966) equation is used to estimate sediment transport capacity of the flow (Bingner and Theurer, 2005). AnnAGNPS utilizes the HUSLE (Hydro-geomorphic Universal Soil Loss Equation) model (Theurer and Clarke, 1991) to determine sediment delivery ratios of total sediment to the stream network.

\section{Study area}

The Carapelle watershed is located in Puglia region (Southern Italy). It originates from the flyschoid formations of the Daunia Mountains and crosses the Tavoliere floodplain before flowing into the Adriatic sea (Figure 1; Table 1). Soils predominantly belong to the class of Entisols and have a fine clayey-loamy texture, are low in organic matter content, natural fertility and water-holding capacity. The plain and the low hilly areas ( $80 \%$ of the watershed surface) are mainly used for cereal cultivation and olive orchards, whereas in the higher slopes deciduous oaks 
and hardwoods (Quercus pubescens and Quercus cerris) and pasture conditions are present. The climate is typically Mediterranean, with rainfalls ranging from 450 to $800 \mathrm{~mm} /$ year and average temperatures from 10 to $16^{\circ} \mathrm{C}$. The flow regime is torrential and flood events are mainly associated with intensive, short-term rainfalls. Suspended sediment, even during floods, is mainly characterized by fine particles.

\section{Monitoring stream flow and suspended sediment}

Continuous stream flow and sediment load data derived from the monitoring station located in the Carapelle torrent at OrdonaCastelluccio dei Sauri Bridge (Figure 2). The station is equipped with an ultrasound water stage meter and a water stage recorder, with remote data transmission. Runoff is determined by converting the record of water levels into a record of flows using the experimental water discharge rating curve given by the National Hydrografic Service, that is responsible for the runoff measurements. An infrared optic probe (Hach-Lange SOLITAX Hs-line) is used to monitor suspended sediments. The probe measures suspended sediments by coupling backscattering and nephelometric photodetectors (Gentile et al., 2010). The instrument is contained in a shelter tube through a pulley, a float and a counterweight group that is anchored to a bridge pier to protect the instrument from the impact of coarse material in the flow and to prevent any potential measuring errors caused by incident radiant energy straying into the infrared field. The instrument is controlled through a data acquisition system that is powered by solar panels and is able to measure high solid concentrations with the capability to reduce watery medium and light interferences.

Gentile et al. (2010) tested the probe in the laboratory in order to evaluate the functional capacity of the instrument and to assess the effects of the different grain size and solid fractions on measurements. The instrument was field calibrated during the flood events of 20072009 to evaluate the efficacy of the housing system, to identify a calibration curve of the instrument for the specific torrent and to assess the type of the relationship between the SSC measured by the instrument and the gravimetric SSC. The SSC of all samples was measured using the gravimetric method and compared with the data observed by the optical sensor.

Thirty-six events observed during 2007-2011 were used for the application of the AnnAGNPS model, this does not include all runoff and sediment yields that occurred in the watershed, some storm events were not sampled due to equipment malfunctions or temporary lack of power to the sensor, caused by the solar panels. In general, the small number of flood events during the rainy season is another characteristic of Mediterranean watersheds.

Considering that AnnAGNPS do not consider base flow, the surface runoff separation from baseflow was performed (Figure 3) using the filtering algorithm developed by Eckhardt (2005). Baseflow separation

Table 1 Main characteristics of the Carapelle watershed, mouth at Ordona bridge.

\begin{tabular}{lcc}
\hline Watershed area & $\mathrm{km} 2$ & 506.2 \\
Maximum altitude & $\mathrm{m}$ a.s.l & 1075.0 \\
\hline Average altitude & $\mathrm{m}$ a.s.l. & 466.0 \\
Minimum altitude & $\mathrm{m}$ a.s.l & 120.0 \\
\hline Main channel length & $\mathrm{km}$ & 52.2 \\
Main channel slope & $\%$ & 1.8 \\
\hline Mean watershed slope & $\%$ & 8.2 \\
Time of Concentration & hour & 10 \\
\hline
\end{tabular}

is required in numerous widely used hydrological and erosive models and must be considered in monthly models (Mouelhi et al., 2006). The filtering algorithm has the following equation:

$$
b_{k}=\frac{\left(1-B F I_{\max }\right) a b_{k-1}+(1-a) B F I_{\max } Q_{1}}{1-a B F I_{\max }}
$$

where $b_{k}$ is the base flow at time stamp $k ; b_{\mathrm{k}-1}$ is the base flow at the previous time step; $Q_{t}$ is the measured total flow; $B F I_{\max }$ is a constant that can be interpreted as the maximum value of long term ratio of base flow to total stream flow; $a$ is the recession constant. The filter parameter " $a$ " and $B F I_{\max }$ were calculated using the hydrograph recession curve analysis and the optimization module developed by Kyoung et al. (2010).

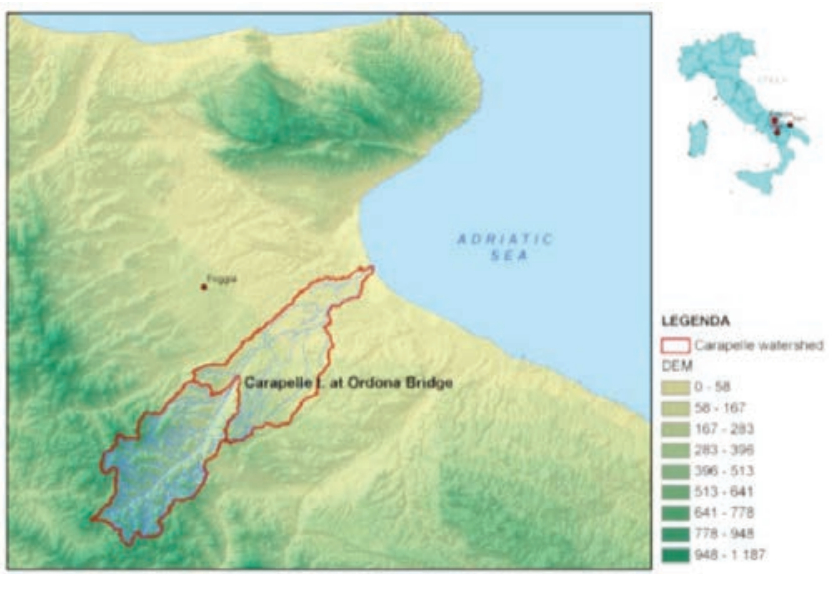

Figure 1. Carapelle watershed in Southern Italy.

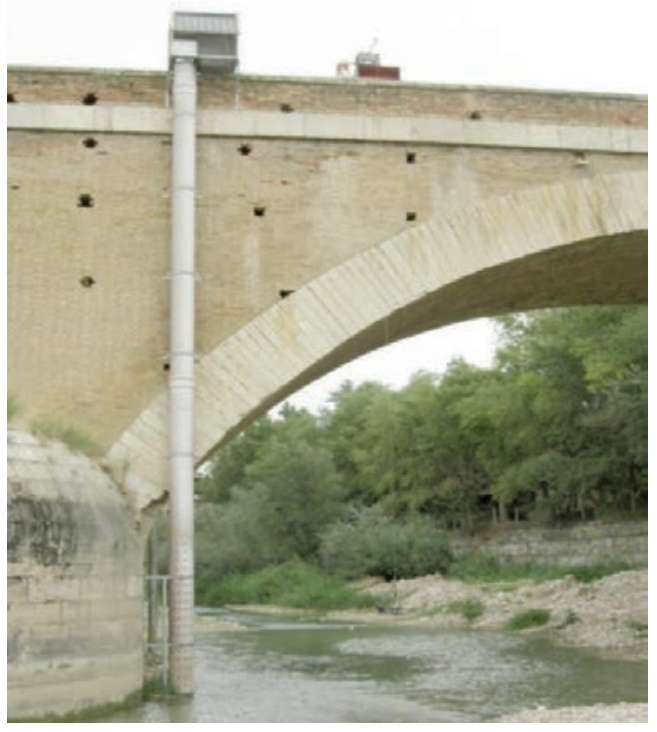

Figure 2. Continuous stream flow and sediment load data monitoring station. 


\section{Input Data Preparation}

\section{Topography}

The topographic features were defined using the Digital elevation map $(90 \mathrm{~m})$ of the Carapelle watershed provided by the SRTM (Shuttle Radar Topographic Mission) project carried out by the NASA (National Aeronautics and Space Administration) and the NGA (National Geospatial-Intelligence Agency).

The watershed discretization into homogeneous drainage areas ("cells") and the hydrographic network segmentation into channels ("reaches") was performed using the GIS interface incorporated into AnnAGNPS. The geometry and the density of the drainage network were modeled by setting the critical source area to 50 ha and the minimum source channel length to $250 \mathrm{~m}$, resulting in 1006 cells and 416 reaches, which allowed a suitable representation of the watershed.

\section{Land Use and Field Management}

Land use data are based on the 1:100 000 CORINE Land Cover data set (CLC2000). The accuracy of the data set has been validated in other studies by comparing images with ground based photography and field surveys (EEA, 2006). Based on the CLC2000 dataset, land uses were grouped in six main classes: cropland (winter wheat and olive-groves), rangeland, forest, urban, fallow and pasture. Figure 4 reports the surface area covered by each land use. The CORINE data set only distinguishes between arable land and agricultural or non-agricultural land use types, therefore information on crop growth and cropping methods were needed. In particular the crop data and management information required by the model include the units harvested, surface and subsurface decomposition, crop residue, root mass, canopy cover, management scheduling and agricultural operations.

The winter wheat crop parameters were based on RUSLE guidelines and internal databases (Renard et al., 1997) while four management practices were assigned to represent the local conditions of the watershed (Table 2).

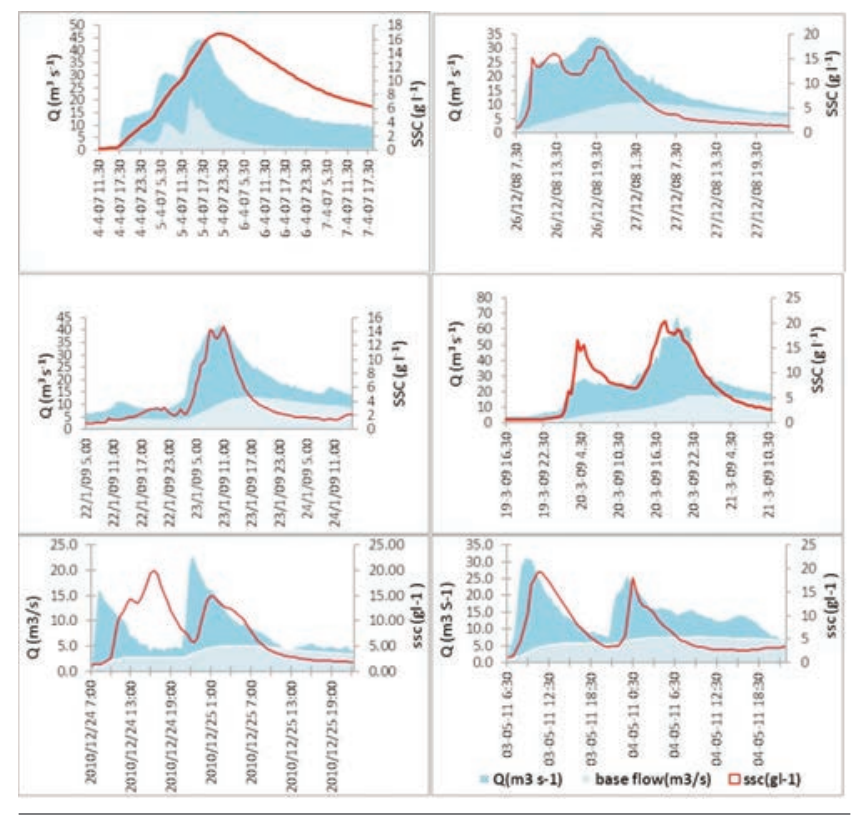

Figure 3. Measured stream flow, suspended sediments and calculated baseflow for some flow events registered during the period 2007-2011
Planting operations occurred in September and harvesting operations occurred in June. After harvest, the land is prepared with other management practices (tillage, semi-deep drill). The tillage effects are linked to the management of crop residues, control of competing vegetation, incorporation of amendments, preparation of the seedbed and, in semi-arid zones, moisture conservation.

A new database was created for the olive grove crops describing: the root density, the estimated aerial coverage of the crop canopy and the average rainfall drop height, which were assumed to remain constant respectively at $30000 \mathrm{~kg}$ ha-1, $50 \%$ and $1 \mathrm{~m}$ (Galvagni et al., 2006). Tillage operations and organic fertilizers applications were scheduled (Table 2) as they are required to aerate soil, improve water storage,

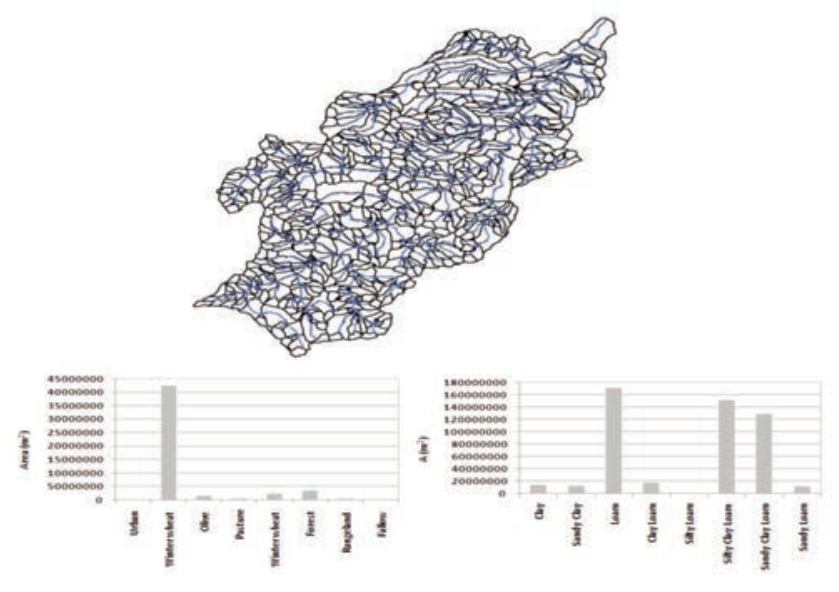

Figure 4. Layout of the discretized watershed with the surface area covered by each land use and soil texture class.

Table 2. Management scheduling for cropland.

\begin{tabular}{cccc}
$\begin{array}{c}\text { Winter wheat } \\
\text { Event date } \\
\text { Management } \\
\text { scheduling }\end{array}$ & \multicolumn{2}{c}{$\begin{array}{c}\text { Olive grove } \\
\text { Event date }\end{array}$} & $\begin{array}{c}\text { Management } \\
\text { scheduling }\end{array}$ \\
$06 / 01$ & Harvest grain & $01 / 01$ & $\begin{array}{c}\text { Organic fertilizer } \\
\text { application }\end{array}$ \\
$09 / 01$ & Tillage & $04 / 01$ & Tillage operation \\
\hline $09 / 20$ & Begin crop growth & $06 / 01$ & Shallow tillage operation \\
$12 / 15$ & Semi-deep drill & $08 / 01$ & Shallow tillage operation \\
\hline $11 / 01$ & Harvest & $12 / 01$ & $\begin{array}{c}\text { Organic fertilizer } \\
\text { application }\end{array}$ \\
\hline
\end{tabular}

Table 3. Soil properties for each textural class.

\begin{tabular}{lcccc} 
Soil structure & $\begin{array}{c}\mathrm{K} \text { factor } \\
\left(\mathrm{t} \mathrm{h} \mathrm{MJ}^{-1} \mathrm{~mm}^{-1}\right)\end{array}$ & Wp (\%) & $\mathrm{Fc}(\%)$ & $\mathrm{ks}\left(\mathrm{mm} \mathrm{h}^{-1}\right)$ \\
Clay & 0.035 & 0.3 & 0.42 & 4.5 \\
Sandy clay & 0.034 & 0.26 & 0.37 & 14.89 \\
\hline Loam & 0.043 & 0.11 & 0.24 & 12.7 \\
Clay Loam & 0.03 & 0.2 & 0.34 & 2.02 \\
\hline Silty clay & 0.035 & 0.27 & 0.42 & 1.49 \\
Silty-loam & 0.044 & 0.1 & 0.27 & 9.88 \\
\hline Silty-clay-loam & 0.043 & 0.18 & 0.37 & 4.59 \\
Sandy-clay-loam & 0.033 & 0.17 & 0.26 & 4.83 \\
\hline Sandy-loam & 0.006 & 0.2 & 0.1 & 32.92 \\
\hline
\end{tabular}


remove weeds and avoid soil compaction.

Single non-cropland databases were assigned to rangeland, forest, urban, fallow and pasture field types. The root system parameters of the forest field type were derived from literature (Galvagni et al., 2006).

The crop management factor $\mathrm{C}$ for each period was calculated by the model based on land use, canopy cover, surface cover, surface roughness and soil moisture conditions. The $P$ factor used was set to 1 since no significant management operations were implemented to reduce soil erosion.

\section{Soil properties}

Soil parameters such as the textural classes, saturated hydraulic conductivity and soil depths were extracted from the project ACLA2 (scale 1:100 000), a research program funded by the Puglia Region aimed at agro-ecological characterization of the region on the basis of laboratory tests, field observations and photo interpretation of aerial photographs and satellite images (Caliandro et al., 2005). The soil depth is considered as the portion of soil that allows the development of functional and organic roots, where the term "functional" refers to soil moisture dynamics while "organic" considers the interactions involved in the organic matter production (Caliandro et al., 2005). On the basis of the USDA triangle the mean percentages by weight of sand, clay and silt, were assigned to each textural class. The percentage of organic matter was derived from the project Octop of the European Soil Data Centre (ESDAC, 2003).

In the Carapelle watershed soils have weak or no diagnostic subsurface layers and are generally well drained. Hydraulic conductivity decreases as soil pore diameters decreases: in the root zone $(\mathrm{h}<110$ $\mathrm{cm}$ ) saturated hydraulic conductivity can be assumed to have high values $\left(\mathrm{k}_{\mathrm{sat}}>3.6 \mathrm{~cm} / \mathrm{h}\right)$, but the drainage can be restricted below the root zone $\left(\mathrm{k}_{\mathrm{sat}}<0.036 \mathrm{~cm} / \mathrm{h}\right)$. ). For this reason the permeability of the soil layer used to simulate subsurface flows and to account for the groundwater processes was referred to the less permeable layer at $150 \mathrm{~cm}$. The average soil hydraulic properties, water content at wilting point Wp, field capacity Fc and saturated hydraulic conductivity ks, were calculated for each soil type (Table 3) using the Saxton and Rawls (2006) pedotransfer functions.

The RUSLE soil erodibility factor "K", was estimated using the Lal and Elliot (1994) equation. Nine types of soils were identified and the average erodibility factors were calculated (Table 3). Based on each land use (cropland, fallow, rangeland, forest, pasture, urban) and Hydrologic Soil Group (A, B, C, D) the initial Curve Numbers were defined (Table 4).

\section{Climate}

Meteorological data such as daily maximum temperature, daily minimum temperature, daily precipitation, daily sky cover, daily wind speed and daily dew point temperature were used as the input climate data for the simulations. The spatial distribution of climatic data were assessed using the Thiessen weighting procedure related to the eight rain gauges located in the watershed or in the surrounding area.

The rainfall erosivity factor $\mathrm{R}$ was estimated by (Bisantino et al., 2013) considering the mean monthly precipitation of the period 1979 1999, according to Ferro et al. (1999), resulting in $960.70 \mathrm{MJ} \mathrm{mm}$ ha year $^{-1}$.

\section{Model calibration and validation}

Both the hydrological and erosion components of AnnAGNPS were calibrated/validated in a logical order taking into account a previous sensitivity analysis performed by Bisantino et al (2013) for the most meaningful parameters of the model ( $R, K, C$ and $P$ factors of USLE equation, $\mathrm{CN}$ curve number and MN Manning's roughness coefficient). The parameter calibration order used was first surface runoff, then peak flow and finally sediment load. Input parameters affecting surface runoff and peak flow were first calibrated because of their influence on the other output.

The calibration/validation process of runoff was carried out by modifying the initial values of $\mathrm{CN}$, which represent a key factor in obtaining accurate prediction of runoff and sediment yield (Yuan et al., 2001; Shrestha et al., 2006) and the most important input parameter to which the runoff is sensitive (Yuan et al., 2001; Baginska et al., 2003).

For the calibration of peak flows and sediment yields, both $24 \mathrm{~h}$ rainfall distributions (types I and Ia) typical of a Pacific maritime climate with wet winters and dry summers outlined by the Natural Resource Conservation Service (NRCS) and described by SCS (1972) were considered. Based on the analysis of observed rainfall events at different rain gauges performed by Bisantino et al (2013) it was found that both storm types well represent the meteorological conditions of Mediterranean zones. The storm type "I" was found to give better predictions of peak discharge so it was set during simulations.

The sediment yields were evaluated at the event scale by adjusting the Manning's roughness coefficient (whichaffects the RUSLE C factor).

The observed flood events have runoff volumes ranging from 0.2 to $8.6 \mathrm{~mm}$ (94593 to $4336938 \mathrm{~m}^{3}$ ), peak discharges between 1.6 and 73.6

Table 5. Coefficients and difference measures for model evaluation and their range of variability.

\begin{tabular}{|c|c|c|}
\hline Coefficient & Equation & Range of variability \\
\hline $\begin{array}{l}\text { Coefficient of efficiency } \\
\text { (Nash and Sutcliffe, 1970) }\end{array}$ & & $-\infty$ to 1 \\
\hline
\end{tabular}

Willmott index 1982

0 to 1

\begin{tabular}{|c|c|c|c|c|}
\hline \multirow[t]{2}{*}{ Cover type } & \multicolumn{4}{|c|}{ Initial curve numbers for hydrologic soil groups } \\
\hline & A & B & C & D \\
\hline Cropland & 72 & 81 & 88 & 91 \\
\hline Fallow & 76 & 85 & 90 & 93 \\
\hline Rangeland & 35 & 56 & 70 & 77 \\
\hline Forest & 43 & 65 & 76 & 82 \\
\hline Pasture & 49 & 69 & 79 & 84 \\
\hline Urban & 89 & 92 & 94 & 95 \\
\hline
\end{tabular}

Coefficient of determination $\mathrm{R}^{2}$

0 to 1

Coefficient of determination $\mathrm{R}^{2}$

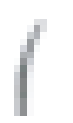

Coefficient of residual mass

$-\infty$ to $\infty$

(Loague and Green, 1991) 
$\mathrm{m}^{3} / \mathrm{s}$ and sediment loads between 202 to $103216 \mathrm{t}\left(0.4\right.$ to $\left.204 \mathrm{~g} \mathrm{~m}^{-2}\right)$.The years considered (2007-2011) had precipitation rates ranging from $544.0 \mathrm{~mm}$ in 2007 to $873 \mathrm{~mm}$ in 2010 .

\section{Model Performance Assessment}

The model performance was evaluated at the event scale by qualitative and quantitative approaches. The qualitative approach consisted of visually comparing observed and simulated values. For a quantitative evaluation, a range of both summary and difference measures were used. The summary measures utilized were the mean and standard deviation of both observed and simulated values. For difference measures five evaluation criteria were used to evaluate the model performance: the coefficient of determination $\left(\mathrm{R}^{2}\right)$, the Nash-Sutcliffe coefficient of efficiency (NSE), the Willmott index of agreement (W), the coefficient of residual mass (CRM), and the root mean square error (RMSE). The coefficient of determination, $\mathrm{R}^{2}$, describes the proportion of the total variance in the observed data that can be explained by the model, $\mathrm{R}^{2}$ is an insufficient and often misleading evaluation criterion as large values of $\mathrm{R}^{2}$ can be obtained even when the model-simulated values differ considerably in magnitude; the Nash and Sutcliffe (1970) coefficient of efficiency (NSE) was also used to assess the model efficiency (Table 5). In particular, some authors discussed that NSE is more sensitive to extreme values (Legates and McCabe, 1999; Krause et al., 2005). Willmott (1982) sought to overcome the insensitivity of correlation-based measures to differences in the observed and modelsimulated means and variances by developing the index of agreement. The Coefficient of Residual Mass (CRM) was used to indicate a prevalent model over- or underestimation of the observed values (Loague and Green, 1991). The values considered optimal for these criteria were one for "R2", "NSE" and "W" and zero for "CRM". According to common practice, simulation results are considered good for values of NSE greater than or equal to 0.75 , satisfactory for values of NSE between 0.75 and 0.36 , and unsatisfactory for values below 0.36 (Van Liew and Garbrecht, 2003). Finally, the RMSE describes the difference between the observed and simulated values in the unit of the variable, and it ranges from 0 to $¥$, where zero indicates that there is no difference between model simulations and field observations.To quantify the model accuracy in simulating runoff, peak discharge and sediment load, AnnAGNPS was applied to simulate the entire period 2007-2009. The output efficiency was evaluated as relative error (RE).The RE is the ratio of the total difference between simulated and observed values versus the total observed value. It ranges from minus one to $\infty$ while zero indicates that there is no difference between model simulation and field observation. The smaller the absolute value of a RE, the better performance of the model is:

$$
R E=\frac{|P-O|}{O}
$$

where $\mathrm{P}$ is the predicted value and $\mathrm{O}$ is the observed value. The relative error was used to solve the problems of significance and units, as it is the ratio between the absolute error and the absolute value of the correct value.

\section{Management Practices}

The management practices have an important role when applied as a plan of soil and water conservation. The aim of the simulation was to understand the entity of the sediment yield reduction at a watershed scale in a Mediterranean environment when applying agricultural or environmental measures of soil erosion control; for this reason these measures were applied at a very large scale in the watershed. The different scenarios that have been considered are representative of situations that it is difficult to find in real cases; nevertheless, they could be
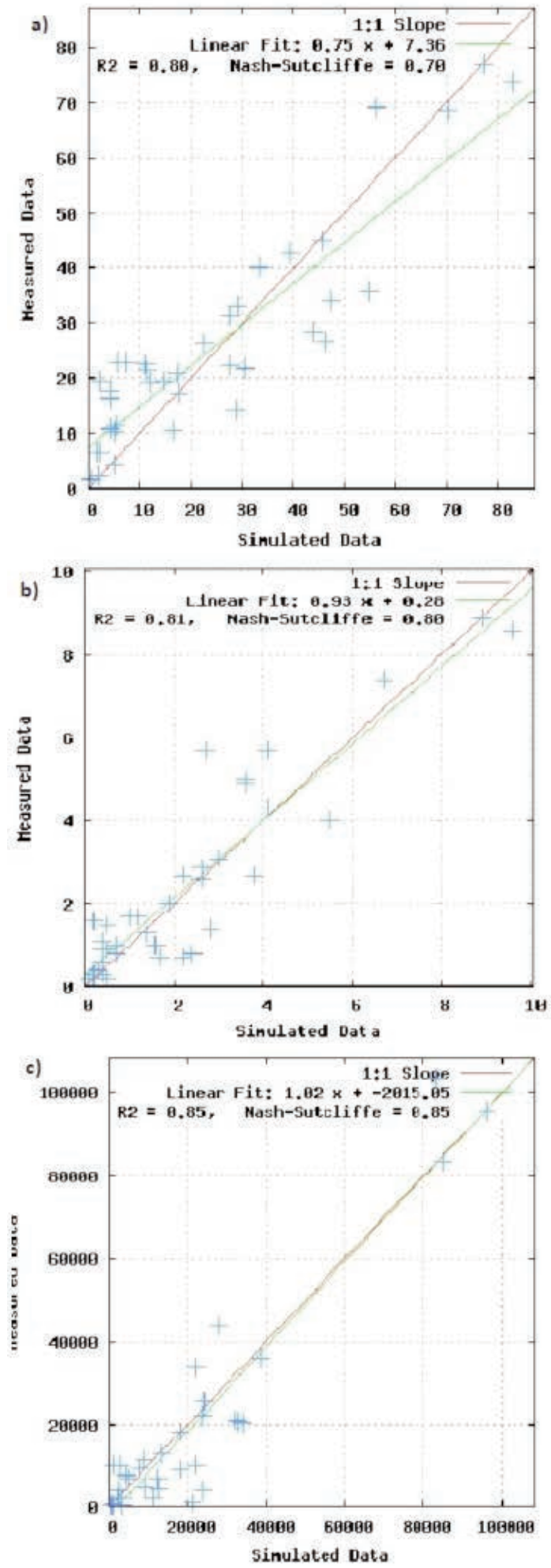

Figure 5. Comparison of 36 observed and simulated events: (a) peak flow, (b) runoff and (c) sediment yield in the Carapelle watershed 
a good starting point to design a combination of agricultural and environmental measures that can have a good impact on the reduction of sediment yield in the watershed. Such a process, that should be carefully carried out to take into account the real conditions of the watershed in terms of physical, environmental, agricultural and socio-economic features, could drive to the definition of the so called Best management practices.

To evaluate the effectiveness of Management Practices (MPs) on sediment yield, the following alternative scenarios were simulated using AnnAGNPS at the monitoring site, and the sediment yield at the watershed outlet was compared with the results obtained from the validation simulation file:

$1^{\text {st }}$ scenario (S1) the wheat crop was assumed to be converted into forest. During this simulation, the input file was modified to replace the field land use type "Winter wheat" into the "Forest" land use type; $\mathrm{CN}$ and MN were set to forest. This scenario can be considered representative of the situation before the establishment of agriculture in the area.

$2^{\text {nd }}$ scenario (S2) using the Vegetated Streams. In this simulation, the reach vegetation code was changed to assign a code for a vegetated stream instead of no-vegetated streams.

$3^{\text {rd }}$ scenario (S3) A crop rotation of Corn \& soybean was assumed to be planted instead of the winter wheat crop. The winter wheat cover crop was not planted and the field was fallow, with residue from soybeans and cotton left on the surface. The data base of corn and soybean were based on the internal data base of the model: the corn was planted in $15^{\text {th }}$ of April of the $1^{\text {st }}$ year of simulation and harvested in the $25^{\text {th }}$ of October of the same year, while the Soybean was assumed to be planted in the $1^{\text {st }}$ of April of the following year and harvested in the $25^{\text {th }}$ of October of the same year. For both crops, no tillage operations were supposed, and the plant residues were left in place.

$4^{\text {th }}$ scenario (S4) no tillage in winter wheat. In this simulation, the input file was modified to exclude any crop tillage operation in the Management operation data.

\section{Results and Discussion}

\section{Calibration and validation}

The model performance was calibrated at the event scale utilizing 11 observed erosive events registered during the period 2007 -2008. In uncalibrated mode, the model tends to over-predict the runoff volumes, so the initial CNs were properly decreased to get runoff results closer to the observed ones. The same results were found in semi-arid conditions by Licciardello et al. (2007).

At the end of calibration, runoff depths were in general slightly over predicted (see the negative value of the CRM coefficient in Table 6). The mean value and the standard deviation of the simulated runoff depths were close to the observed corresponding values, with a difference equal approximately to 10 and $2 \%$ respectively. The coefficient of determination and the Nash-Sutcliff efficiency factor achieved after the runoff calibration were good (Table 6). Similar results were found at the event scale by other authors like Yuan et al. (2001), Shrestha et al. (2006) and Shamshad et al. (2008).

After calibration, the mean predicted value of peak flow was $14 \%$ different from the mean observed value, however, the difference between predicted and simulated values raises for the standard deviation to be more than $40 \%$ (Table 6). High efficiency is shown by the coefficient of determination $\mathrm{R}^{2}$ value $\left(\mathrm{R}^{2}=0.81\right)$, while other statistical indexes (NSE and RMSE) show a satisfactory prediction (Table 6). Other authors (Zema et al., 2010; Shrestha et al., 2006; Licciardello et $a l ., 2007)$ found that the model unsatisfactory predicted peak flows. To calibrate the sediment yield, the MN's roughness coefficient of each cell was modified starting from the initial values taken from TR55

Table 6. Statistics concerning the AnnAGNPS calibration and validation in the Carapelle watershed.

\begin{tabular}{|c|c|c|c|c|c|c|c|}
\hline \multicolumn{8}{|c|}{ Runoff (mm) } \\
\hline Observed & 1.5 & 1.9 & - & - & - & - & - \\
\hline Default simulation & 2.1 & 2.4 & 0.38 & 0.65 & -0.42 & 1.4 & 0.88 \\
\hline Calibrated model & 1.7 & 1.9 & 0.76 & 0.78 & -0.1 & 0.91 & 0.93 \\
\hline \multicolumn{8}{|c|}{ Peak flow $\left(\mathrm{m}^{3} / \mathrm{s}\right)$} \\
\hline Observed & 16 & 14 & - & - & - & - & - \\
\hline Default simulation & 27 & 31 & -1.4 & 0.86 & -0.75 & 21 & 0.78 \\
\hline Calibrated model & 18 & 20 & 0.54 & 0.81 & -0.14 & 9.2 & 0.92 \\
\hline \multicolumn{8}{|c|}{ Sediment yield (kg/m2) } \\
\hline Observed & 0.018 & 0.025 & - & - & - & - & - \\
\hline Default simulation & 0.037 & 0.044 & -0.81 & 0.62 & -1.04 & 0.33 & 0.77 \\
\hline Calibrated model & 0.024 & 0.028 & 0.67 & 0.74 & -0.35 & 0.01 & 0.92 \\
\hline Validation & & & Runoff (mm) & & & & \\
\hline Observed & 2.56 & 2.22 & - & - & - & - & - \\
\hline Simulated & 2.28 & 2.18 & 0.81 & 0.82 & 0.11 & 0.99 & 0.95 \\
\hline \multicolumn{8}{|c|}{ Peak flow $\left(\mathrm{m}^{3} / \mathrm{s}\right)$} \\
\hline Observed & 29 & 18 & - & - & - & - & - \\
\hline Simulated & 26 & 22 & 0.69 & 0.82 & 0.11 & 10.2 & 0.93 \\
\hline \multicolumn{8}{|c|}{ Sediment yield $\left(\mathrm{kg} / \mathrm{m}^{2}\right)$} \\
\hline Observed & 0.036 & 0.05 & - & - & - & - & - \\
\hline Simulated & 0.038 & 0.04 & 0.86 & 0.86 & -0.06 & 0.02 & 0.96 \\
\hline
\end{tabular}


(SCS, 1986). For forest and rangeland, MN values respectively equal to 0.8 and 0.13 were set, while for urban areas, cropland and pasture the initial value of 0.15 was considered. Increasing the value of MN for the different land uses and especially for the cropland (wheat) and urban areas, the tendency of the model to overestimate the suspended sediment yield that is clear in the un-calibrated mode was reduced (see the CRM values before calibration in default simulation and after calibration in Table 6). Generally, a good correlation between observed and simulated data was obtained, as reported by the Nash Sutcliffe efficiency index and the coefficient of determination $\mathrm{R}^{2}$; the value of the root mean square error was close to zero, showing a good model efficiency in predicting sediment yield.

The results obtained in the calibration phase were used for model validation, that was carried out using 25 events recorded during the period 2009-2011. As confirmed by the statistical indexes, an excellent performance of the model was observed in simulating runoff volumes (Table 6). The model performance in predicting peak discharges is satisfactory (see RMSE and NSE values) although according to the $\mathrm{R}^{2}$ values a good correlation between observed and simulated data exist. Sediment yield values were perfectly predicted and an acceptable overestimation is observed.

Figure 5 reports the visual comparison between simulated and observed data for the entire period (thirty-six events). As expected using the calibrated SCS-CNs, the model prediction is good for runoff and sediment yield and satisfactory for peak discharge.

After the validation process, it was observed, comparing the statistical indexes, that the model prediction was better in the validation than in the calibration process. To better understand this finding, the relative error (RE) was calculated for two groups of events and represented on a box plot (Figure 6).The first group (26 events) has peak discharges $Q_{p} \leq 30 \mathrm{~m}^{3} \mathrm{~s}^{-1}$ and is representative of low flow events, as previously stated by Gentile et al. (2010) in the same watershed; the second group ( 10 events) has peak discharges $30<Q_{p} \leq 73.6 \mathrm{~m}^{3} \mathrm{~s}^{-1}$ and is representative of high flow events. A difference in the RE values between the two groups was observed, showing that the model better predicts sediment yield for high intensive events and that a larger scatter between simulated and observed sediment yield values exists for low flow events. The same behaviour was observed for peak flows.

As the number of high flow events included in the validation process (25 events, 3 years) is greater than those included in the calibration (11 events, 2 years), this could be the reason why the model did not perform as well in calibration than in validation.

\section{Sediment yield response to alternative Management Practices}

Figure 7 shows the average annual sediment yield (t/ha) at a watershed scale obtained applying four alternative scenarios of Management practices that could be used to reduce soil erosion and sediment loads in the watershed.

In the first scenario (S1), when all the cropland wheat is substituted with forest, the sediment yield is reduced in the watershed, with an average value of $60 \%$ during the whole period of simulation; this land use change would save a total amount of 9.3 t/ha of sediments.

In the second scenario (S2) the use of vegetation along the whole stream network (vegetated streams) reduces the average annual sediment yield by $18.5 \%$ (a total amount of 3 tha), due to the effect of vegetation in retaining sediments from being eroded and conveyed to the watershed outlet.

In the third Scenario (S3) a crop rotation of corn-soybean is hypothetically applied instead of the overall cropland wheat. The average annual sediment yield is reduced by $34 \%$, due to the effect of the continuous cover offered by the crop residue that helped in protecting soil from being eroded. As a quantity, a total amount of 5.3 t/ha of sediments could be saved.

The last scenario (S4) is corresponding to the application of no tillage practices in cropland. Herethe sediment yield could be reduced by up to $18.5 \%$, preventing approximately 3 t/ha of sediments from being lost.

The S1 scenario, that means converting all the cropland into forest and gives the better results in terms of soil erosion control, could be considered as representative of the ancient conditions in the Puglia region (eighteen century) when forest was the prevailing land use and agriculture was not yet extensively estabilished.

The S3 and s4 scenarios can be considered as agriculture-targeted, both give good results in terms of sediment yield reduction, even if the efficiency of crop rotations is approximately two times that of the conservation tillage (no-tillage) practices. Finally, the S2 scenario, that could be considered as environmentally-targeted, has the same efficiency of the agricultural S4 scenario.

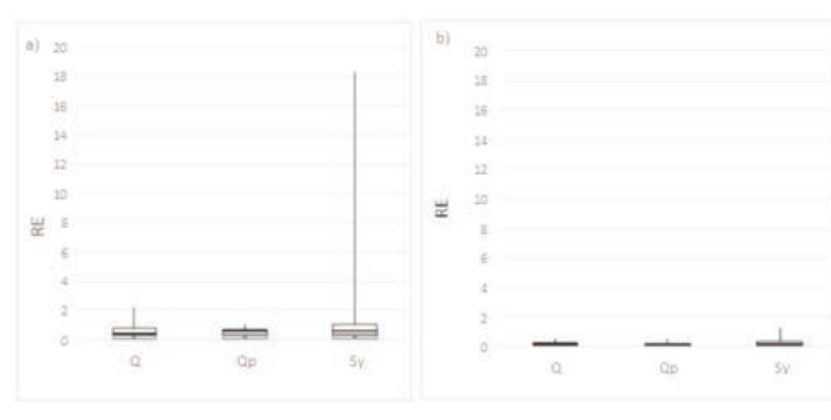

Figure 6. Average relative error (RE) for low flow events (a) and high flow events $(\mathbf{b})$.

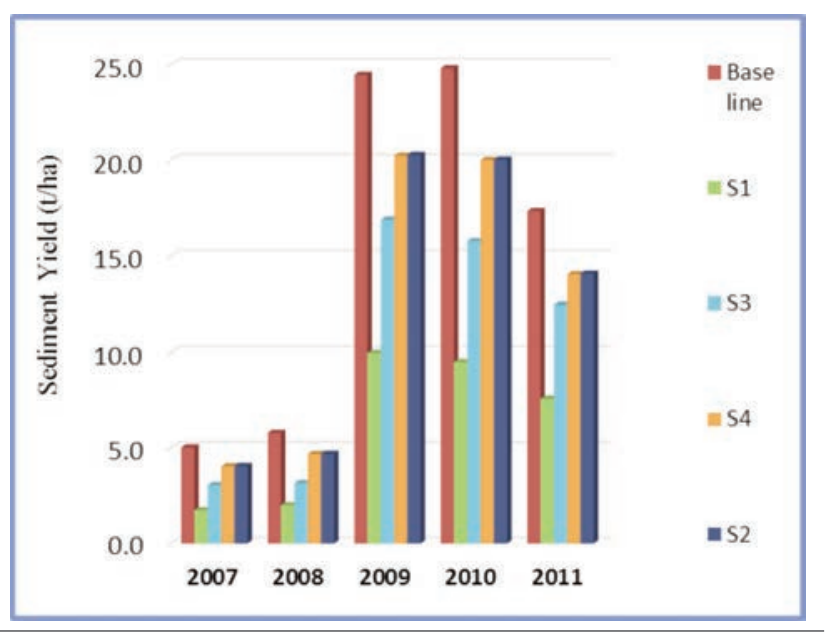

Figure 6. Average relative error (RE) for low flow events (a) and high flow events (b). 


\section{Conclusions}

The AnnAGNPS Model was implemented in the Carapelle, a medium size Mediterranean watershed in southern Italy, using 36 erosive events recorded during the period 2007-2011. The objective of this work was to evaluate the model capacity of predicting sediment yield, runoff, and peak flow in the watershed through a continuous monitoring of runoff and sediment loads. The evaluation process included 2 phases, the first one was the model calibration and the second one was the model validation. The model calibration was performed following an order in which runoff was calibrated first by adjusting the initial curve number values modifying the retention $S$ factor. The impact of the SCS types Ia and I synthetic rainfall distribution was investigated; the SCS storm type I gave the highest efficiency in predicting peak flows and was used in the simulation. Finally, the sediment yield was calibrated by adjusting the Manning roughness coefficient. Comparing predicted to observed data visually and using different statistical indexes, the results showed a good model performance in predicting runoff and sediment yield on the event basis in calibration and validation, while its performance was satisfactory for peak discharge. Generally, the model showed a tendency to better predict high flow events while a great scatter was found between observed and predicted values in case of low flow events. This result is important in semi-arid conditions where the annual sediment transport rate is mostly concentrated in a small number of high erosive events.

Successively the effectiveness of applying some Management practices on the sediment yield reduction at a watershed scale was determined. Based on the simulation results, it is concluded that substituting cropland wheat with forest achieved the highest reduction in sediment yield. A good compromise between agriculture and soil conservation was represented by the crop rotation of corn and soybean, while the scenarios corresponding to the revegetation of the stream banks ("environmentally targeted") and the conservation tillage (no-tillage) in cropland achieved almost similar results. Further analyses need to be performed to evaluate the management practices that are more suitable with the real agriculture and land conditions in the watershed and consequently to assess possible Best management practices (BMPs) in terms of soil erosion control and sediment yield reduction.

\section{References}

Baginska B, Milne-Home W., Cornish P.S. 2003. Modelling nutrient transport in Currency Creek, NSW with AnnAGNPS and PEST. Environ. Modell. Softw. 18: 801-808.

Bagnold, R.A. 1966. An approach to the sediment transport problem from general physics. Prof. Paper 422-J. U.S. Geol. Surv., Reston, VA.

Bakker M.M., Govers G., Rounsevell M.D.A.. 2004. The crop productivity-erosion relationship: an analysis based on experimental work. Catena. 57: 55-76.

Bakker M.M., Govers G., Kosmas C., Vanacker V., Oost K.V., Rounsevell M. 2005. Soil erosion as a driver of land-use change. Agr Ecosyst Environ. 105: 467-481

Evans B.M., Corradini K.J. 2001. BMP Pollution Reduction Guidance Document. Available from: http://www.predict.psu.edu /Downloads/BMPManual.pdf Accessed: January 2013.

Bingner R.L., Theurer F.D. 2005. AnnAGNPS technical processes documentation, version 3.2. 0xford. Miss.: USDA ARS National Sedimentation Laboratory.

Bisantino T., Gentile F., Trisorio Liuzzi G. 2011. Continuous Monitoring of Suspended Sediment Load in Semi-Arid Environments. In: S.S. Ginsberg (ed.) Sediment Transport. ISBN 978-953-307-189-3. InTech, Available from: http://www.intechopen.com/articles/show/ title/continuous-monitoring-of-suspended-sediment-load-in-semiarid-environments Accessed: May 2012

Bisantino T., Bingner R., Chouaib W., Gentile F., Trisorio Liuzzi G. 2013. Estimation Of Runoff, Peak Discharge And Sediment Load At The Event Scale In A Medium-Size Mediterranean Watershed Using The Annagnps Model. Land Degrad. Dev. doi: 10.1002/ldr.2213.

Bosch D., Theurer F., Binger R., Felton G., Chaubey I. 2001. Evaluation of the AnnAGNPS water quality model. In. J.L. Parsons, D.L. Thomas, and R.L. Huffman (eds.): Agricultural Non-point Source Models: Their Use and Application. Southern Cooperative Series Bulletin 398. Available at: http://s1004.okstate.edu/S1004/RegionalBulletins/Modeling-Bulletin/modeling-bulletin.pdf. Accessed: March 2012.

Caliandro A., Lamaddalena N., Stellati M., Steduto P. 2005. Caratterizzazione agroecologica della Regione Puglia in funzione della potenzialità produttiva: Progetto Acla 2. Bari.

Cazorzi, F. 1996. Watershed oriented digital terrain model. User manual, Win95 version, 80. Internal report. Padua, Italy: University of Padova, Agripolis Campus, IDEA Laboratory.

Cazorzi, F., Dalla Fontana G. 1996. Un modello distribuito per la valutazione degli effetti idrologici dei mutamenti d'uso del suolo. Proc. Problemi dei grandi comprensori irrigui: esercizio, manutenzione e ammodernamento delle reti di irrigazione. Associazione Italiana di Ingegneria Agraria (1st section), Novara, Italy.

Chow V.T., Maidment D.R., Mays L.W. 1988. Applied Hydrology. McGrawHill Publishing Company, New York.

Eckhardt K. 2005. How to construct recursive digital filters for baseflow separation. Hydrol Process 19: 507-515.

EEA-European Environmental Agency. 2006. The thematic accuracy of Corine land cover 2000 - Assessment using LUCAS. Technical report.

European Soil Data Centre (ESDAC), 2003. The map of organic carbon in topsoils in Europe. Available from http://eusoils.jrc.ec.europa.eu Accessed December 2011.

Fiorentino M, Iacobellis V. 2001. New insights about the climatic and geologic control on the probability distribution of floods. Water Resour. Res. 37(3): 721-730.

Ferro V., Porto P., Yu B. 1999. A comparative study of rainfall erosivity estimation for southern Italy and southeastern Australia. Hydrolog. Sci. J. 44: 3-23.

Fu G., Chen S., McCool D.K. (2006). Modeling the impacts of no-till practice on soil erosion and sediment yield with RUSLE, SEDD, and ArcView GIS. Soil Till. Res. 85(1-2): 38-49.

Galvagni D., Gregori E., Zorn G. 2006. Modelli di valutazione della biomassa radicale di popolamenti forestali. L'Italia forestale e Montana 61 (2): 101-118.

Gentile F., Bisantino T., Corbino R., Milillo F., Romano G., Trisorio Liuzzi G. 2010. Monitoring and analysis of suspended sediment transport dynamics in the Carapelle torrent (southern Italy). Catena 80: 1-8.

Gradzinski R., Baryla J., Doktor M., Gmur D., Gradzinski M., Kedzior A., Paszkowski M., Soja R., Zielinski T., Zurek S. (2003). Vegetationcontrolled modern anastomosing system of the upper Narew River (NE Po-land) and its sediments. Sediment Geol, 157(3-4): 253-276. doi: 10.1016/S0037-0738(02)00236-1.

Krause P, Boyle D.P., Base F. 2005. Comparison of different efficiency criteria for hydrological model assessment. Adv. Geosci. 5: 89-97.

Kyoung J.L. , Youn Shik P., Jonggun K., Yong-Chul S., Nam Won K., Seong Joon K., Ji-Hong J., Bernard A.E. 2010. Development of genetic algorithm-based optimization module in WHAT system for hydrograph analysis and model application. Computers \& 
Geosciences 36(7): 936-944.

Lal R., Elliot W. 1994. Erodibility and erosivity. In: R. Lal (ed.), Soil Erosion Research Methods. Soil and Water Conservation Society and St. Lucie Press.USA., pp 181-208.

Lenzi M.A., Di Luzio M. 1997. Surface runoff, soil erosion, and water quality modelling in the Alpone watershed using AGNPS integrated with a Geographic Information System. European J. Agron. 6(1-2): $1-14$.

Legates D.R., McCabe G.J. 1999. Evaluating the use of 'goodness of fit' measures in hydrologic and hydroclimatic model validation. Water Resour. Res. 35: 233-241.

Loague K, Green R.E. 1991. Statistical and graphical methods for evaluating solute transport models: overview and application. J. Contam. Hydrol. 7: 51-73..

Licciardello F., Zimbone S.M. 2002. Runoff and erosion modeling by AGNPS in an experimental Mediterranean watershed. Proc. ASAE Annual Intl. Meeting/CIGR XVth World Congress. St. Joseph, Mich.: ASAE

Licciardello F., Zema D.A., Zimbone S.M., Bingner R. L. 2007. Runoff and soil erosion evaluation by the AnnAGNPS model in a small Mediterranean watershed. Transactions of the American Society of Agricultural and Biological Engineers (ASABE) 50(5): 1585-1593

Loague K., Green R.E. 1991. Statistical and graphical methods for evaluating solute transport models: Overview and application. J. Contam. Hydrol. 7(1 2): 5173.

Mohammed H., Yohannes F., Zeleke G. 2004. Validation of agricultural non-point source (AGNPS) pollution model in Kori watershed. South Wollo, Ethiopia. Int. J. Appl. Earth Obs. Geoinf. 6: 97-109.

Morgagni A., Marsigli M., Todini E. 1993. Assessment of soil erosion in a number of small ephemeral streams in Calabria and Sicily. Proc. Workshop on Soil Erosion in Semi arid Mediterranean Areas, 137 148. European Society for Soil Conservation, Centro Studi per l'Economia applicata all'Ingegneria.

Mouelhi S., Michel C., Perrin C., Andreassian V. 2006. Stepwise development of a two-parameter monthly water balance model. J Hydrol 318: 200-214.

Nash J.E., Sutcliffe J.V. 1970. River flow forecasting through conceptual models: Part I. A discussion of principles. J Hydrol 10: 282-290.

Pandey A., Chowdary V.M., Mal B.C., Billib M. 2008. Runoff and sediment yield modeling from a small agricultural watershed in India using the WEPP model. J. Hydrol. 348: 305-319.

Parajuli PB, Nelson NO, Frees LD, Mankin KR. 2009. Comparison of AnnAGNPS and SWAT model simulation results in USDA-CEAP agricultural watersheds in south-central Kansas. Hydrological Processes 23(5): 748-763.

Renard K.G., Foster G.R., Weesies G.A., McCool D.K., Yoder D.C. 1997. Predicting Soil Erosion by Water: A Guide to Conservation Planning with the Revised Universal Soil Loss Equation (RUSLE). USDA Handbook No. 703.

Saxton K.E., Rawls W.J. 2006. Soil water characteristic estimates by texture and organic matter for hydrologic solutions. Soil Sci. Soc. Am. J. 70: 1569-1578.

SCS. 1972. National Engineering Handbook, Section 4. Hydrology Soil Conservation Services, U.S., Department of Agriculture, Washington DC.

SCS. 1986. Technical Release 55: Urban Hydrology for small watersheds. Soil Conservation Service, USDA.

Shamshad A., Leow C.S., Ramlah A., Wan Hussin Sanusi W.M.A., Mohd S.A. 2008. Applications of AnnAGNPS model for soil loss estimation and nutrient loading for Malaysian conditions. Int. J. Appl. Earth
Obs. Geoinf. 10: 239-252.

Shrestha S., Mukand S.B., Gupta A., Kazama F. 2006. Evaluation of annualized agricultural nonpoint source model for a watershed in the Siwalik Hills of Nepal. Environ. Model. Softw. 21: 961-975.

Suttles J. B., Vellidis G., Bosch D.D., Lowrance R., Sheridan J.M., Usery E.L. 2003. Watershed scale simulation of sediment and nutrient loads in Georgia coastal plain streams using the annualized AGNPS model. Trans. ASAE 46(5): 1325-1335.

Theurer F.D., Clarke C.D. 1991. Wash load component for sediment yield modeling. Proc. of the Fifth Federal Interagency Sedimentation Conf., Las Vegas, NV, March 18-21,1991. pp. 7-1 to 78.

Theurer F.D., Cronshey R.G. 1998. AnnAGNPS - Reach routing processes. Proc. First Federal Interagency Hydrologic Modeling Conference. Las Vegas, NV, April 19-23, 1998. pp. 1-25 to1-32.

Thornton C. I., Abt S. R., Clary W. P. 1997. Vegetation influence on small stream siltation1. J. Am. Water Resour. Assoc., 33(6): 1279-1288.

USDA-ARS. 2005. Generation of weather Elements for Multiple applications. Available online: http://www.nwrc.ars.usda.gov /models/gem/index.html (verified May 2007)??

USDA-ARS. 2006. AnnAGNPS - Annualized Agricultural Non-point Source Pollution Model. Available from: http://www.ars.usda.gov/Research/docs.htm?docid=5199 Accessed November 2011.

USDA-SCS. 1986. Urban hydrology for small watersheds. Technical release 55, 2nd ed., NTIS PB87- 101580. USDA, Springfield, VA.

Van Liew M.W., Garbrecht J. 2003. Hydrologic simulation of the Little Washita River experimental watershed using SWAT. J. Am. Water Resour. Assoc. 39: 413-426.

Van Liew M. W., Garbrecht J. 2003. Hydrologic simulation of the Little Washita River experimental watershed using SWAT. J. Am. Water Resour. Assoc. 39(2): 413426.

Willmott C.J. 1981. On the validation of models. Phys. Geogr. 2: 184194.

Willmott C.J. 1982. Some comments on the evaluation of model performance. Bull. Am. Meteorol. Soc. 63: 1309-1313.

Wolman M.G., Gerson R. 1978. Relative scales of time and effectiveness of climate in watershed geomorphology. Earth Surface Processes. 3(2): 189-208.

Yuan Y., Bingner R.L., Rebich R.A. 2001. Evaluation of AnnAGNPS on Mississippi Delta MSEA watershed. Trans. ASAE 44(5): 1183-1190.

Yuan Y., Bingner R.L., Theurer F.D. 2006. Subsurface flow component for AnnAGNPS. Appl. Eng. in Agric. 22(2): 231-241.

Yuan Y, Locke MA, Bingner RL. 2008. Annualized Agricultural NonPoint Source model application for Mississippi Delta Beasley Lake watershed conservation practices assessment. Journal of Soil And Water Conservation 63 (6): 542-551.

Yoon J. 1996. Watershed scale non-point source pollution modelling and decision support system based on a model- GIS-RDBMS linkage. Proc. AWRA Symposium on GIS and Water Resources, Ft Lauderale, FL, 2-16.

Zema D.A., Bingner R.L., Denisi P., Govers G., Licciardello F. Zimbone, S.M. 2010. Evaluation of runoff, peak flow and sediment yield for events simulated by the AnnAGNPS model in a belgian agricultural watershed. Land Degrad. Develop. Land Degrad. Develop. 23: 205215.

Zou C.B., Ffolliott P.F., Wine M. 2010. Streamflow responses to vegetation manipulations along a gradient of precipitation in the Colorado River Basin. For. Ecol. Manage., 259(7): 1268-1276. doi: DOI: 10.1016/j.foreco.2009.08.005. 